Katarzyna StokŁosa

Uniwersytet Warszawski

\title{
ODPOWIEDZIALNOŚĆ PODMIOTÓW ZBIOROWYCH NA NOWYCH ZASADACH A OBECNE ROZWIĄZANIA PRAWNE. WYBRANE ZAGADNIENIA
}

\section{UWAgI WPROWADZAJĄCE}

Problem odpowiedzialności karnej podmiotów zbiorowych jest istotnym elementem systemu bezpieczeństwa interesów finansowych, zarówno w systemie krajowym, jak i na gruncie unijnym oraz międzynarodowym. Jest standardem obowiązującym we współczesnych systemach prawnych i stanowi przejaw obiektywizowania odpowiedzialności karnej.

Uregulowanie odpowiedzialności osób prawnych jest jednym z priorytetów Unii Europejskiej. Traktat o Unii Europejskiej w art. 29 wskazuje, że korupcja i nadużycia finansowe są przestępstwami, których skuteczne zwalczanie jest celem, w ramach dawnego III filaru. Skonkretyzowany obowiązek uregulowania odpowiedzialności podmiotów zbiorowych wynika z Konwencji o ochronie interesów finansowych

1 Szerzej o koncepcjach teoretycznych odpowiedzialności podmiotów zbiorowych W. Zalewski, Odpowiedzialność podmiotu zbiorowego w prawie karnym - w poszukiwaniu racjonalności, «Gdańskie Studia Prawnicze» 37.1/2017, s. 389-404.

2 Dz. U. z 2004 r. Nr 90, poz. 864/2 ze zm. 
Wspólnot Europejskich z 26 lipca 1995 r. ${ }^{3}$, która nakłada na państwa członkowskie obowiązek przyjęcia ustawodawstwa pozwalającego na pociągnięcie do odpowiedzialności osób zarządzających przedsiębiorstwami lub innych osób, posiadających prawo podejmowania decyzji lub sprawowania kontroli (w tym również osoby prawne). Przy czym konwencja pozwala na wybór modelu odpowiedzialności, a kwestią zasadniczą jest skuteczność przyjętej regulacji. Również państwa z Organizacji Współpracy Gospodarczej i Rozwoju (OECD) zdecydowały się na uregulowanie kwestii odpowiedzialności podmiotów zbiorowych w akcie prawnym o charakterze międzynarodowym, tj. Konwencji o zwalczaniu przekupstwa zagranicznych funkcjonariuszy publicznych w międzynarodowych transakcjach handlowych ${ }^{4}$, która zobowiązuje strony do usankcjonowania odpowiedzialności zarówno osób fizycznych, jak i prawnych. Przy czym państwo będące stroną konwencji może wybrać reżim odpowiedzialności, który zastosuje wobec podmiotu zbiorowego (karny, administracyjny, cywilny), podobnie jak warunki tej odpowiedzialności ${ }^{5}$.

Pomimo możliwości wyboru charakteru odpowiedzialności, znaczna część państw europejskich opowiada się za podejściem punitywnym do działań podmiotów zbiorowych. We Francji, Holandii i Belgii kwestie te zostały uregulowane w kodeksach karnych tych państw, natomiast w Polsce i Niemczech - w odrębnych ustawach. Jednakże często sankcje

3 Konwencja o ochronie interesów finansowych Wspólnot Europejskich, sporządzona w Brukseli 26 lipca 1995 r., Protokół do Konwencji o ochronie interesów finansowych Wspólnot Europejskich z 26 lipca 1995 r., sporządzony w Dublinie 27 września 1996 r., Protokół w sprawie interpretacji w trybie orzeczenia wstępnego przez Trybunał Sprawiedliwości Wspólnot Europejskich Konwencji o ochronie interesów finansowych Wspólnot Europejskich z 26 lipca 1995 r., sporządzony w Brukseli 29 listopada 1996 r., oraz Drugi Protokół do Konwencji o ochronie interesów finansowych Wspólnot Europejskich z 26 lipca 1995 r., sporządzony w Brukseli 19 czerwca 1997 r. (Dz. U. z 2009 r. Nr 208, poz. 1603).

4 Konwencja o zwalczaniu przekupstwa zagranicznych funkcjonariuszy publicznych w międzynarodowych transakcjach handlowych, sporządzona w Paryżu 17 grudnia 1997 r. (Dz. U. z 2001 r. Nr 23, poz. 264).

5 C. NowaK, Dostosowywanie prawa polskiego do instrumentów międzynarodowych dotyczacych korupcji - raport, Warszawa 2004, s. 3-35. 
karne nie są tak skuteczne jak odpowiedzialność cywilna ${ }^{6}$. Fakt ten potwierdzają stosunkowo niskie kary przewidziane w obowiązującej ustawie z 28 października 2002 r. o odpowiedzialności karnej podmiotów zbiorowych za czyny zabronione pod groźbą kary ${ }^{7}$, których wysokość wynosi od 1 tys. do 5 mln zł, przy czym orzeczona kara nie może przekroczyć 3\% przychodu osiągniętego w roku obrotowym, w którym popełniono czyn zabroniony. Dlatego odpowiedzialność karna nie jest tak dotkliwa dla ich interesów, a co więcej, działalność przestępcza często przynosi im korzyść. Powoduje to, że nie tylko w Polsce skazywanie podmiotów kolektywnych jest fikcjąa .

$\mathrm{Z}$ danych przedstawionych w Informatorze Statystycznym Ministerstwa Sprawiedliwości wynika, że w 2018 r. liczba spraw prowadzonych przeciwko podmiotom zbiorowym wyniosła 4 , a liczba spraw zakończonych merytorycznie, tj. wyrokiem bądź orzeczeniem - 5. Z kolei w 2017 r. liczba spraw zawisłych przed sądami powszechnymi wyniosła 14, z czego merytorycznie rozstrzygnięto o 32 sprawach. Te niskie statystyki utrzymywały się również w poprzednich latach. Przykładowo, w 2010 r. do sądów powszechnych wpłynęło 6 spraw, a merytorycznie rozstrzygnięto 13. Z kolei średnie kary, jakie były orzekane wobec podmiotów zbiorowych, nie przekraczały $1000 \mathrm{zł}$, a najwyższa z orzeczonych kar nie przekroczyła kilkunastu tysięcy złotych. Często zdarzało się, że koszty postępowania sądowego przewyższały karę finansową nałożoną na podmiot $^{9}$. Co więcej, organy międzynarodowe (np. Grupa Robocza OECD

6 V.S. Khana, A Political Economy Theory Of Corporate Crime Legislation, «Boston U.L.REV Working Paper» 220.3-4/2003, s. 3-9.

7 Tekst jedn.: Dz. U. z 2018 r. poz. 703 ze zm.; dalej: u.o.p.z.

8 J.C. Coffe, Does Unlawful Mean Criminal? Reflections on the Disappearing Tort/ Crime Distinction in American Law, «Center for Law and Economic Studies, Columbia University School of Law» 193.71/1991, s. 216-219.

9 Dane dotyczące liczby prowadzonych spraw przeciwko podmiotom zbiorowym pochodzą ze strony Informatora Statystycznego Ministerstwa Sprawiedliwości:

https://isws.ms.gov.pl/pl/bazastatystyczna/opracowania-jednoroczne/. Natomiast dane dotyczące kar orzekanych wobec podmiotów zbiorowych zostały uzyskane w wyniku przeanalizowania bazy orzeczniczej systemów informacji prawnych Lex oraz Legalis. 
ds. Przekupstwa w Międzynarodowych Transakcjach Handlowych) ${ }^{10}$ podnosiły wobec Polski zarzut, że unikanie odpowiedzialności karnej przez osoby prawne, w sytuacji gdy nie jest możliwe ujęcie i osądzenie osoby fizycznej działającej w ich imieniu, stanowi lukę w skutecznej implementacji przepisów międzynarodowych i tym samym utrudnia wykrywanie i ściganie sprawców niebędących osobami fizycznymi ${ }^{11}$.

Odpowiedzią na te problemy ma być proponowany przez rząd projekt ustawy o odpowiedzialności podmiotów zbiorowych za czyny zabronione pod groźbą kary, którego celem jest zwiększenie skuteczności zwalczania przestępczości gospodarczej przede wszystkim poprzez zaostrzenie kar finansowych ${ }^{12}$. Projekt wprowadza zupełnie nowy model odpowiedzialności szeroko rozumianych osób prawnych, wzorowany na systemie holenderskim i francuskim.

Istota zakładanych zmian polega w szczególności na wyeliminowaniu uprzedniego skazania osoby fizycznej jako warunku odpowiedzialności podmiotu zbiorowego ${ }^{13}$, czyli konieczności uzyskania prejudykatu (tj. wyroku za czyn zabroniony stanowiący przestępstwo bazowe) ${ }^{14}$. Kwestia odpowiedzialności osób prawnych będzie mogła zostać

10 Por. Rekomendacje dotyczące uczciwości w służbie publicznej, https://www. oecd.org/gov/ethics/integrity-recommendation-polish.pdf (dostęp: 12 grudnia 2018 r.).

11 Uzasadnienie do projektu ustawy o odpowiedzialności podmiotów zbiorowych za czyny zabronione pod groźbą kary i zmianie niektórych ustaw, numer projektu UD 74, Sejm VIII kadencji.

12 Projekt ustawy o odpowiedzialności podmiotów zbiorowych za czyny zabronione pod groźbą kary i zmianie niektórych ustaw, numer projektu UD 74, Sejm VIII kadencji.

13 Poza skazaniem prawomocnym wyrokiem karnym ustawodawca uzależnia odpowiedzialność karną podmiotu zbiorowego od wydania wobec osoby fizycznej wyroku warunkowo umarzającym wobec niej postępowanie karne albo postępowanie w sprawie o przestępstwo skarbowe, orzeczenie o udzielenie tej osobie zezwolenia na dobrowolne poddanie się odpowiedzialności albo orzeczenie sądu o umorzeniu przeciwko niej postępowania z powodu okoliczności wyłączającej ukaranie sprawcy.

14 Wymóg prejudykatu zawarty w ustawie uznawany jest przez OECD za najbardziej istotną barierę w nadaniu skuteczności odpowiedzialności osób prawnych w Polsce por. T. DAR Kowski, Plany ministerstwa sprawiedliwości zmian legislacyjnych służących ograniczeniu szarej strefy w Polsce, https://www.pwc.pl/pl/pdf/szara-strefa-2016.pdf (dostęp: 12 grudnia 2018 r.). 
rozstrzygnięta niezależnie od uprzedniego skazania osoby fizycznej. Zmiana ta umożliwi prowadzenie postępowania w sprawie odpowiedzialności podmiotu zbiorowego jednocześnie z procesem przeciwko osobie fizycznej. Ponadto projekt zakłada znaczne podwyższenie progu i pułapu ustawowej wysokości kar pieniężnych, a także odejście od powiązania wysokości kary z wysokością przychodu osiągniętego przez podmiot zbiorowy. Zrezygnowano z zamkniętego katalogu przestępstw, których popełnienie umożliwi wszczęcie postępowania przeciwko osobie prawnej. Zgodnie z projektem będzie to możliwe w przypadku popełnienia dowolnego przestępstwa w związku z jej działalnością. Novum w zaproponowanej ustawie stanowi ochrona osób zgłaszających nieprawidłowości (tzw. sygnaliści), którzy w interesie publicznym zgłaszają istotne błędy w organizacji podmiotu zbiorowego mogące prowadzić do popełnienia czynu zabronionego. Podmiotowi, który nie przeprowadzi postępowania na podstawie zgłoszenia sygnalisty, nie usunie nieprawidłowości lub zwolni sygnalistę, może grozić kara nawet $60 \mathrm{mln}$ zł.

Ramy niniejszej pracy nie pozwalają na szczegółową analizę wszystkich zmian zaproponowanych przez ustawodawcę. Dlatego autorka skupi się na analizie wybranych zagadnień materialnoprawnych, poprzez porównanie obowiązującego i przyszłego stanu prawnego, a następnie przedstawi postulaty i uwagi de lege ferenda do analizowanego projektu. W szczególności zostaną zestawione i przeanalizowane koncepcje w zakresie konstrukcji podmiotu zbiorowego oraz zakres jego odpowiedzialności w związku z uzyskaniem korzyści majątkowej. Stan prawny przedstawiony w niniejszym artykule opiera się na rozwiązaniach zawartych w rządowym projekcie ustawy o odpowiedzialności podmiotów zbiorowych za czyny zagrożone karą, który wpłynął do Sejmu 11 stycznia 2019 r. $^{15}$

15 Projekt ustawy o odpowiedzialności podmiotów zbiorowych za czyny zagrożone karą, UD 74, http://orka.sejm.gov.pl/Druki8ka.nsf/Projekty/8-0201211-2019/\$file/8-020-1211-2019.pdf (dostęp: 12 grudnia 2018 r.). Projekt, w dniu oddania artykułu (12 stycznia 2019 r.), został skierowany do zaopiniowania przez Biuro Legislacyjne. 


\section{Definicja podmiotu zbiorowego. ObeCne i PRZyszŁe ROZWIĄZANIA}

Artykuł2 u.o.p.z. wskazuje na definicję podmiotu zbiorowego, który jest rozumiany szeroko jako osoba prawna oraz jednostka organizacyjna niemająca osobowości prawnej, której odrębne przepisy przyznają zdolność prawną. Przy czym istnieje wiele podmiotów wyłączonych spod odpowiedzialności karnej na gruncie tej ustawy. Są to: Skarb Państwa, jednostki samorządu terytorialnego i ich związki, jak również spółki handlowe z udziałem Skarbu Państwa, jednostki samorządu terytorialnego lub związki takich jednostek, spółka kapitałowa w organizacji, podmiot w stanie likwidacji oraz przedsiębiorca niebędący osobą fizyczną ${ }^{16}$.

Powyższa definicja budzi w doktrynie wiele wątpliwości choćby w zakresie uznania spółki cywilnej za podmiot zbiorowy. Zdaniem Aleksandry Antoniak-Dróżdż ${ }^{17}$ spółka cywilna nie jest takim podmiotem, bowiem nie ma osobowości prawnej, nie ma też zdolności prawnej, co pozwoliłoby ją uznać za jednostkę organizacyjną niemającą osobowości prawnej. Zdaniem autorki trudno również zgodzić się z tezą o możliwości uznania katalogu podmiotów z art. 2 u.o.p.z. za otwarty i domniemania podstaw odpowiedzialności spółki cywilnej. A contrario, Adam Bartosiewicz ${ }^{18}$ wskazuje, że przedsiębiorcy niebędący osobami fizycznymi są podmiotami zbiorowymi w rozumieniu ustawy. Zatem spółka cywilna, w której wspólnikami są spółki z ograniczoną odpowiedzialnością, może być traktowana jako podmiot zbiorowy na gruncie obowiązującej ustawy.

Niestety, projekt nie wskazuje rozwiązania powyższego problemu. Co więcej, sama definicja podmiotu zbiorowego zaproponowana w projekcie jest nieprawidłowo skonstruowana. Ustawodawca posługuje się definicją zakresową, która przez podmiot zbiorowy rozumie osobę prawną oraz jednostkę organizacyjną niemającą osobowości prawnej, której odrębne

16 A. Antoniak-Dróżdż, Zakres podmiotowy ustawy o odpowiedzialności podmiotów zbiorowych, «PiP» 72.2/2017, s. 111-120.

17 A. ANTONIAK-Dróżdż, op. cit., s. 121-127.

18 A. Bartosiewicz, Spółki osobowe a odpowiedzialność podmiotów zbiorowych, «Przegląd Prawa Handlowego» 9/2013, s. 53-58. 
przepisy przyznają zdolność prawną, w tym również spółki handlowe z udziałem Skarbu Państwa, jednostki samorządu terytorialnego lub związki takich jednostek, spółki kapitałowe w organizacji, podmioty w stanie likwidacji oraz przedsiębiorcy niebędący osobą fizyczną, z wyłączeniem Skarbu Państwa i jednostek samorządu terytorialnego i ich związków. Definicja ta wprowadza niekonsekwentne wyszczególnienie tylko niektórych rodzajów podmiotów zbiorowych. Przykładowo, spółka kapitałowa z udziałem Skarbu Państwa jest osobą prawną tak samo jak każda inna spółka kapitałowa, a postawienie jej w stan likwidacji nie pozbawia jej przymiotu osoby prawnej. Poza tym nadal nie jest jasny status spółki cywilnej, która z jednej strony nie jest osobą prawną ani jednostką organizacyjną nieposiadającą osobowości prawnej i jako taka nie mieści się w przedstawionej definicji podmiotu zbiorowego, a z drugiej strony rozumiana jako przedsiębiorca niebędący osobą fizyczną (sytuacja, w której wspólnikami spółki cywilnej są spółki z ograniczoną odpowiedzialnością) jest objęta zakresem ustawy ${ }^{19}$.

Na krytykę zasługuje również wyłączenie Skarbu Państwa z definicji podmiotu zbiorowego. W obecnym stanie prawnym, jak również w nowych przepisach ustawodawca konsekwentnie deroguje ten podmiot z zakresu pojęcia podmiotu zbiorowego, co powoduje brak odpowiedzialności państwa na gruncie wskazanej ustawy ${ }^{20}$. Konstrukcja odpowiedzialności Skarbu Państwa nie jest niczym nowym. Przykładowo art. 417 k.c. ${ }^{21}$ przewiduje, że Skarb Państwa, jednostka samorządu terytorialnego lub inna osoba prawna wykonująca z mocy prawa władzę publiczną odpowiada za niezgodne z prawem działanie lub zaniechanie przy wykonywaniu tej władzy. Co prawda, na gruncie kodeksu cywilnego mamy do czynienia z odpowiedzialnością odszkodowawczą, jednak sama kara pieniężna - stanowiąca w swej istocie sankcję - jest

19 Stanowisko to zostało również zaaprobowane w: Uwagach do projektu ustawy zgłoszonych przez Deloitte Legal z 18 czerwca 2018 r.

20 W projekcie ustawy z 5 grudnia 2018 r. ustawodawca dopuszcza odpowiedzialność spółek z udziałem Skarbu Państwa, ale sam Skarb Państwa jest wyłączony spod tej odpowiedzialności.

${ }^{21}$ Ustawa z 23 kwietnia 1964 r. - Kodeks cywilny (tekst jedn.: Dz. U. z 2018 r. poz. 1025 ze zm.). 
rekompensatą finansową za zaistniałą szkodę. Z kolei działanie bądź zaniechanie niezgodne $\mathrm{z}$ prawem (wskazane w art. 417 k.c.) jestprzestępstwem $^{22}$. Jest to niekonsekwencja ustawodawcy, który z jednej strony obciąża Skarb Państwa odpowiedzialnością odszkodowawczą spowodowaną czynem niedozwolonym, a z drugiej, podmiot ten jest wolny od jakiejkolwiek odpowiedzialności karnej ${ }^{23}$.

\section{KonstrukCJA PRZESTĘPSTWA PODMIOTU ZBIOROWEgO}

W obowiązującym stanie prawnym mamy do czynienia z dwustopniową odpowiedzialnością podmiotów zbiorowych ${ }^{24}$, tzn. najpierw czyn zabroniony osoby fizycznej, następnie odpowiedzialność osoby prawnej. Pierwszy stopień wynika in principio z art. 3 u.o.p.z., który wskazuje, że podmiot zbiorowy odpowiada za czyn zabroniony, którym jest szeroko ujęte zachowanie osoby fizycznej działającej w jego imieniu lub w intere$s i e^{25}$. Jednakże samo pojęcie działania w interesie bądź w imieniu nie jest

22 Definicja zaproponowana przez L. GARDockiEgo wskazuje, że przestępstwem jest czyn (działanie lub zaniechanie) człowieka, zabroniony przez ustawę pod groźbą kary jako zbrodnia lub występek, zawiniony i społecznie szkodliwy w stopniu większym niż znikomy. Por. L. Gardocki, Pojęcie przestępstwa i podział przestępstw w polskim prawie karnym, «Annales Universitatis Mariae Curiae-Sklodowska Lublin-Polonia» 15.2/2013, s. 29-39.

23 D. KARKUT, Odpowiedzialność podmiotów zbiorowych - ujęcie prawnoporównawcze, http://bibliotekacyfrowa.pl/Content/42786/04_Daniel_Karkut.pdf, s.130-133 (dostęp: 12 grudnia 2018 r.).

24 W. ZaLEWSKI, op. cit., s. 5-6.

25 Zgodnie z art. 3 u.o.p.z. podmiot zbiorowy podlega odpowiedzialności za czyn zabroniony, którym jest zachowanie osoby fizycznej: 1) działającej w imieniu lub $\mathrm{w}$ interesie podmiotu zbiorowego w ramach uprawnienia lub obowiązku do jego reprezentowania, podejmowania w jego imieniu decyzji lub wykonywania kontroli wewnętrznej albo przy przekroczeniu tego uprawnienia lub niedopełnieniu tego obowiązku, 2) dopuszczonej do działania w wyniku przekroczenia uprawnień lub niedopełnienia obowiązków przez osobę, o której mowa w pkt 1,3) działającej w imieniu lub w interesie podmiotu zbiorowego, za zgodą lub wiedzą osoby, o której mowa w pkt 1, 3a) będącej przedsiębiorcą, który bezpośrednio współdziała z podmiotem zbiorowym w realizacji celu prawnie dopuszczalnego. 
zdefiniowane i budzi wiele wątpliwości. Katarzyna Ondrysz ${ }^{26}$ wskazuje, że przez działanie w interesie należy rozumieć każdy czyn zmierzający do dokonania przysporzenia na rzecz podmiotu zbiorowego, a działanie w imieniu to takie, do którego działający został upoważniony bądź na mocy przepisu ustawowego, bądź umownego (np. pełnomocnictwa). Ponadto, trzeba wykazać, że zachowanie osoby fizycznej przyniosło lub mogło przynieść podmiotowi zbiorowemu korzyści choćby niemajątkowe. W praktyce postępowanie dowodowe $\mathrm{w}$ tym zakresie jest trudne, bowiem podmiot z łatwością może wykazać, że działanie jego pełnomocnika nie przyniosło mu żadnych korzyści ${ }^{27}$.

Drugi stopień tej odpowiedzialności wynika $\mathrm{z}$ art. 5 u.o.p.z. i odnosi się do quasi-winy podmiotu zbiorowego ${ }^{28}$. Popełnienie czynu zabronionego przez osobę fizyczną następuje w sytuacji braku należytej staranności w jej wyborze albo co najmniej braku należytego nadzoru nad nią ze strony organu lub przedstawiciela podmiotu zbiorowego. Poza wykazaniem co najmniej braku należytej staranności bądź braku odpowiedniego nadzoru odpowiedzialność karna podmiotu zbiorowego jest uzależniona od popełnienia przez tę osobę jednego $\mathrm{z}$ enumeratywnie wyliczonych przestępstw. Zgodnie z art. 16 u.o.p.z. są to czyny zabronione $\mathrm{z}$ grupy przestępstw przeciwko: obrotowi gospodarczemu, obrotowi pieniędzmi i papierami wartościowymi, a także przestępstwa łapownictwa i płatnej protekcji. Zatem aby pociągnąć do odpowiedzialności karnej podmiot zbiorowy, należy nie tylko skazać osobę fizyczną działającą w imieniu lub w interesie tego podmiotu, lecz także wykazać brak należytej staranności w wyborze tej osoby, ocenić, czy jej zachowanie przyniosło lub mogło przynieść korzyści (chociażby niematerialne), jak również udowodnić, że działanie osoby fizycznej wypełnia znamiona jednego z przestępstw, wskazanych w art. 16 u.o.p.z.

26 K. Ondrysz, Przesłanki odpowiedzialności podmiotów zbiorowych za czynyzabronione pod groźbą kary - po nowelizacji, «Nowa Kodyfikacja Postępowania Karnego» 20.1/2016, s. 89-105.

${ }^{27}$ Jako przykład można przytoczyć niewykazywanie zysku w rocznych sprawozdaniach finansowych i tzw. kreatywną księgowość.

28 W. ZALEWSKI, op. cit., s. 10. 
Na gruncie obowiązującej ustawy wykazanie winy podmiotu zbiorowego w nieprawidłowym nadzorze bądź wyborze osoby fizycznej jest trudne, jeżeli podmiot skutecznie wdrożył system criminal compliance $^{29}$. Ponadto, we współczesnych stosunkach gospodarczych znaczenie zyskuje działalność korporacyjna, charakteryzująca się znacznym sposobem skomplikowania i rozmiarami organizacyjnymi. Zatem uzależnienie możliwości pociągnięcia do odpowiedzialności spółki od wcześniejszego osądzenia osoby fizycznej (gdzie jej identyfikacja ze względu na działalność i strukturę korporacyjną często jest niemożliwa) powoduje znikomą efektywność dotychczasowych rozwiązań prawnych.

W odpowiedzi na te problemy, w niniejszym projekcie wskazano, że zasadniczym sposobem realizacji znamion czynu zabronionego przez podmiot zbiorowy jest działanie jego organów. Obecnie podmioty zbiorowe odpowiadają za czyny osób fizycznych, nie zaś za czyny własne. Zmiana tego stanu rzeczy polega na oparciu konstrukcji odpowiedzialności podmiotu zbiorowego na podstawie teorii tzw. winy anonimowej ${ }^{30}$ oraz na przypisaniu odpowiedzialności karnej bezpośrednio podmiotowi zbiorowemu, wzorowanej na prawie francuskim i holenderskim. To właśnie Francja jako jedno z pierwszych państw w Europie, obok Holandii, wprowadziła odpowiedzialność karną podmiotów zbiorowych $^{31}$, która została uregulowana w nowym francuskim kodeksie karnym (Nouveau Code Pénal) ${ }^{32}$, a nie jak powszechnie w osobnej ustawie. W art. 121-2 francuskiego kodeksu karnego wskazano, że odpowiedzialności karnej podlegają osoby prawne prawa prywatnego: spółki

29 A. Krawczy K, A. Gisman, Criminal compliance jako środek zapobiegania odpowiedzialności podmiotów zbiorowych za czyny zabronione pod groźbą kary, «Monitor Prawa Handlowego» 1/2015, s. 3-5.

30 Jest to koncepcja pozwalająca na pociągnięcie do odpowiedzialności określonego podmiotu bez wskazywania zawinienia przez konkretną osobę, występująca w wielu ustawodawstwach europejskich, m.in. w prawie holenderskim, francuskim i austriackim.

31 S. ToszKa, Odpowiedzialność podmiotów zbiorowych we francuskim i polskim prawie karnym. Analiza porównawcza, «Czasopismo Prawa Karnego i Nauk Penalnych» $12.1 / 2008$, s. 282-285.

32 Obowiązujący francuski kodeks karny uchwalono 22 lipca 1992 r., wszedł w życie 1 marca 1994 r., zastępując kodeks karny Napoleona z 1810 r. 
prawa cywilnego lub handlowego, stowarzyszenia, związki zawodowe, konsorcja gospodarcze, a także zagraniczne osoby prawne na ogólnych zasadach właściwości prawa francuskiego ${ }^{33}$. Przy czym odpowiedzialność karna osób prawnych wykazuje jednak pewne odmienności, przykładowo ustawodawca stworzył odrębny katalog kar, które mogą być orzekane wobec osób prawnych ${ }^{34}$. Dalej poszedł ustawodawca holenderski, który zrównał odpowiedzialność karną osób fizycznych i prawnych. W art. 51 holenderskiego kodeksu karnego z 1881 r. ${ }^{35}$ wskazano, że przestępstwo może być popełnione przez osobę fizyczną oraz osobę prawną. Przy czym jeżeli przestępstwo zostało popełnione w ramach działalności podmiotu zbiorowego, można skazać tylko osobę prawną bądź tylko osobę fizyczną wykonującą lub kierującą wykonaniem czynu przestępnego, lub obie te osoby łącznie. Wobec tak uregulowanej odpowiedzialności, na podmiocie zbiorowym ciążą szczególnego rodzaju obowiązki, między innymi przyjęcie zasady racjonalnego delegowania kompetencji oraz szczegółowe reguły kontroli i nadzoru.

Wzorem regulacji europejskich rodzimy ustawodawca wychodzi z założenia, że jeżeli szeroko rozumiana osoba prawna, która zgodnie $z$ art. 38 k.c. działa przez swoje organy, odpowiada za podjęte działania bądź za zaniechania tych organów i ich członków (art. 5 ust. 1 projektowanej ustawy), nie wyłączając odpowiedzialności karnej. Koncepcja odpowiedzialności podmiotu zbiorowego za czyny własne zaproponowana w projekcie zasługuje na aprobatę, ale samo sformułowanie art. 5 ust. 1 projektu nie jest trafne. Ustawodawca stosuje zabieg legislacyjny polegający na wskazaniu, że podmiot zbiorowy odpowiada za czyn zabroniony, „którego znamiona zostały wyczerpane przez działanie lub zaniechanie pozostające bezpośrednio w związku z prowadzoną przez ten podmiot działalnością". Tak wskazana definicja wydaje się zbyt szeroka, bowiem ustawodawca nie precyzuje, jak należy ten związek

33 Y. Maguard, Les grandes articles du code pénal, Paris 2017, s. 60-71.

34 D. Karkut, Odpowiedzialność..., s. 117-120.

35 Po licznych nowelizacjach holenderskiego kodeksu karnego z 1881 r., w wyniku których dopuszczono w ograniczonym zakresie odpowiedzialność karną podmiotów kolektywnych, dopiero nowelą z 23 czerwca 1976 r. kwestię tę objęto kompleksową regulacją. 
rozumieć. Może to doprowadzić do sytuacji, w której czyny mające marginalny związek z działalnością danego podmiotu będą skutkowały jego odpowiedzialnością ${ }^{36}$. Z łatwością można wyobrazić sobie sytuację, w której nowy pracownik placówki banku popełnia przestępstwo z art. 299 k.k. ${ }^{37}$, tj. przyjmie środki płatnicze pochodzące z przestępstwa, działając $\mathrm{w}$ porozumieniu $\mathrm{z}$ inną osobą, $\mathrm{z}$ którego korzyści ponosi przede wszystkim sam pracownik, a instytucja, którą reprezentował, nie wiedziała o tym procederze i nie poniosła żadnych istotnych korzyści z tego tytułu, a związek tego podmiotu z bankiem był niewielki. Czy w takiej sytuacji zostały wyczerpane znamiona przestępstwa, enumeratywnie określone w nowej ustawie ${ }^{38}$, typizujące niezachowanie należytej staranności wymaganej w danych okolicznościach? Sąd Najwyższy w uchwale I KZP 5/15 ${ }^{39}$ wskazał, że wykładnia 299 k.k. skłaniać musi do szczególnej ostrożności w kontaktach gospodarczych z podmiotami mogącymi dysponować środkami pieniężnymi pochodzącymi z korzyści związanych z popełnieniem czynu zabronionego. Przyjęcie takich środków, nawet w charakterze świadczenia pieniężnego za wykonaną legalnie usługę lub dostawę towaru, może zostać zakwalifikowane jako wyczerpujące znamiona przestępstwa prania pieniędzy. Zatem czy na gruncie nowej ustawy, w tak przedstawionym stanie faktycznym podmiot zbiorowy zostanie pociągnięty do odpowiedzialności?

Podobne konsternacje budzi art. 6 ust. 3 pkt 1 i 2, który wskazuje, że podmiot zbiorowy wyczerpuje znamiona czynu zabronionego w następstwie: co najmniej braku należytej staranności w wyborze osób

36 Por. uwagi do projektu ustawy o odpowiedzialności podmiotów zbiorowych („Projekt”) opublikowanego przez Ministerstwo Sprawiedliwości 28 maja 2018 r., https://legislacja.rcl.gov.pl/docs//2/12312062/12511895/12511898/dokument34757.pdf (dostęp: 12 grudnia 2018 r.).

${ }_{37}$ Ustawa z 6 czerwca 1997 r. - Kodeks karny (tekst jedn.: Dz. U. z 2018 r. poz. 1600 ze $\mathrm{zm}$.).

38 Art. 5 ust. 2 projektu wskazuje, że warunkiem odpowiedzialności podmiotu zbiorowego jest wyczerpanie znamion czynu zabronionego wskutek: 1) działania lub zaniechania organu; 2) umyślnego działania lub zaniechania członka organu; 3) niezachowania przez podmiot zbiorowy ostrożności wymaganej w danych okolicznościach, mimo że można było przewidzieć możliwość popełnienia czynu zabronionego.

39 Uchwała SN z 24 czerwca 2015 r., I KZP 5/15, «OSNKW» 7/2015, poz. 55. 
działających w jego imieniu (np. pełnomocników, członków rady nadzorczej, kadry zarządzającej), w nadzorze nad nimi lub też na takiej nieprawidłowości w organizacji działalności podmiotu zbiorowego, która ułatwiła lub umożliwiła popełnienie czynu zabronionego. O ile ustawodawca definiuje w art. 6 ust. 4 nieprawidłowości w organizacji ${ }^{40}$, to nie wskazuje, jak rozumieć należytą staranność. Jest to pojęcie związane z prawem zobowiązań (art. 355 k.c.) i odnosi się do odpowiedzialności kontraktowej, a nie karnej ${ }^{41}$. Co prawda ustawodawca wskazuje w uzasadnieniu, że wzorzec należytej staranności z reguły jest formułowany na poziomie przeciętnej staranności, ale w dalszej części uzasadnienia precyzuje, że przedsiębiorca, na przykład spółka będąca podmiotem zbiorowym, w obrocie gospodarczym jest profesjonalistą i wzorzec taki musi uwzględniać szczególną zdolność przewidywania, zapobiegliwość oraz rzetelność w sposobie działania, a także duże wymagania w zakresie jego wiedzy i umiejętności praktycznych ${ }^{42}$. Wobec tego, jakie standardy należy stosować wobec podmiotu (dotyczące przeciętnej staranności czy kwalifikowanej, wymaganej w danych warunkach)?

40 Nieprawidłowości w organizacji podmiotu zbiorowego polegają w szczególności na: nieokreśleniu zasad postępowania na wypadek zagrożenia popełnienia czynu zabronionego lub skutków niezachowania reguł ostrożności; nie został określony zakres odpowiedzialności organów podmiotu zbiorowego, innych jego komórek organizacyjnych, jego pracowników lub osób uprawnionych do działania w jego imieniu lub interesie, określenie tego zakresu; nie została określona osoba lub komórka organizacyjna, nadzorująca przestrzeganie przepisów i zasad regulujących działalność podmiotu, który jest co najmniej średnim przedsiębiorcą (art. 7 ust. 1 pkt 3 ustawy z 6 marca 2018 r. - Prawo przedsiębiorców); organ podmiotu zbiorowego lub osoba fizyczna uprawniona do jego reprezentowania, podejmowania w jego imieniu decyzji lub sprawowania nadzoru, w związku z jej działaniem w interesie lub na rzecz tego podmiotu, wiedział o nieprawidłowości w organizacji, która ułatwiła lub umożliwiła popełnienie czynu zabronionego.

${ }^{41}$ A. Olejniczak, art. 355 k.c., [w:] Kodeks cywilny. Komentarz, III: Zobowiązania - część ogólna², red. A. KidyBA, Lex 2014.

42 Ustawodawca wskazuje, że wiedza powinna dotyczyć w szczególności znajomości przepisów prawnych obowiązujących w zakresie prowadzonej działalności gospodarczej (por. orzeczenie SN z 17 sierpnia 1993 r., III CRN 77/93, «OSN» 3/1994, poz. 69, oraz wyrok SA w Poznaniu z 8 marca 2006 r., I ACa 1018/05, Lex nr 186161). 
Na gruncie obowiązujących przepisów nie sposób jednoznacznie wyinterpretować, jakie wymogi stawiane są podmiotom zbiorowym w zakresie zachowania należytej staranności i uniknięcia ewentualnej odpowiedzialności karnej. Można jedynie domniemywać, że chodzi o wdrożenie odpowiednich procedur (compilance) i właściwych systemów monitorowania, takich jak regulaminy i wytyczne, które służą zapobieganiu nadużyciom oraz pokazują wzorzec zachowania osób pracujących w organizacji w przypadku, gdy do takiego nadużycia dojdzie. Jednakże podstawy odpowiedzialności karnej nie mogą być przedmiotem jakichkolwiek domniemań. Co więcej, powinny być dokładnie określone w ustawie, tak aby możliwe było rozpoznanie, jakie czyny są zabronione. W momencie podjęcia decyzji o popełnieniu przestępstwa musi istnieć sformułowany czytelnie ustawowy opis znamion czynu zabronionego, tak aby możliwe było przypisanie sprawcy winy. W aspekcie zasady nullum crimen sine lege certa ustawodawca powinien przykładać szczególną wagę do zasady przyzwoitej legislacji czy do pozycji metody językowej w zakresie wykładni przepisów wyrażających znamiona odpowiedzialności karnej. W perspektywie konstytucyjnej wymóg dostatecznej ustawowej określoności ma zracjonalizować proces stosowania norm karnych będących równocześnie gwarancją dochowania wymogów wynikających z konstytucyjnej zasady proporcjonalności (art. 31 ust. 3 Konstytucji). Podstawowe elementy znamion czynu zabronionego powinny zostać jednoznacznie wyrażone w tekście ustawy, a przepisy blankietowe, klauzule generalne czy sformułowania niedookreślone często uniemożliwiają dokonanie właściwej subsumpcji i przypisanie winy ${ }^{43}$.

W kontekście zasady nullum crimen sine lege certa uzasadnione wątpliwości budzi również art. 8 projektu ustawy, który w sprawach nieuregulowanych odsyła do części ogólnej kodeksu karnego. W pierwotnym brzmieniu projektu z 5 września 2018 r. ustawodawca wskazywał na „odpowiednie” stosowanie przepisów kodeksu karnego, natomiast po autopoprawce złożonej 1 października 2018 r. przepisy kodeksu karnego stosuje się „wprost”. Ustawodawca nie precyzuje, w jakim zakresie

43 W. Wróbel, A. Zoll, Polskie prawo karne, część ogólna², Kraków 2010, s. 101-102. 
następuje odpowiednie stosowanie przepisów kodeksu karnego, w zakresie błędu, form stadialnych, jak również dyrektyw co do orzekania o karze i środkach karnych wobec podmiotów zbiorowych. W projekcie ustawy brak jest dyrektyw co do wymiaru kary, zatem zgodnie z art. 8 projektu należy stosować odpowiednio rozdział VI kodeksu karnego („Zasady wymiaru kary i środków karnych”), który odwołuje się do prewencji ogólnej, celów wychowawczych kary czy prewencji generalnej, które w żaden sposób nie przystają do zasad orzekania o karze podmiotów zbiorowych ${ }^{44}$.

Niemożliwe jest stosowanie do odpowiedzialności podmiotu zbiorowego każdego przepisu części ogólnej kodeksu karnego. Dlatego skuteczniejsze byłoby wskazanie w art. 8 poszczególnych przepisów części ogólnej kodeksu karnego, które mogą być stosowane wobec podmiotu zbiorowego, albo choćby powrót do regulacji sprzed 1 października, która wskazywała na „odpowiednie” stosowanie przepisów części ogólnej kodeksu karnego. Tym bardziej że ustawodawca w tym samym projekcie, w części procesowej (art. 41 projektu) enumeratywnie wskazał, których przepisów kodeksu postępowania karnego ${ }^{45}$ nie stosuje się do odpowiedzialności podmiotów zbiorowych ${ }^{46}$. Dlaczego więc podobnego rozwiązania nie zastosowano do art. 8 ?

44 Wśród nich ustawodawca wymienia m.in.: motywację sprawcy i sposób zachowania się sprawcy, zwłaszcza w razie popełnienia przestępstwa na szkodę osoby nieporadnej ze względu na wiek lub stan zdrowia, popełnienie przestępstwa wspólnie z nieletnim, rodzaj i stopień naruszenia ciążących na sprawcy obowiązków, rodzaj i rozmiar ujemnych następstw przestępstwa, właściwości i warunki osobiste sprawcy, sposób życia przed popełnieniem przestępstwa i zachowanie się po jego popełnieniu, a zwłaszcza staranie o naprawienie szkody lub zadośćuczynienie w innej formie społecznemu poczuciu sprawiedliwości, a także zachowanie się pokrzywdzonego.

45 Ustawa z 6 czerwca 1997 r. (tekst jedn.: Dz. U. z 2018 r. poz. 1987 ze zm.).

46 Chodzi m.in. o umorzenie absorpcyjne, negatywne przesłanki procesowe, regulacje związane z oskarżycielem posiłkowym czy przepisy dotyczące wszczęcia, odmowy wszczęcia czy umorzenia śledztwa. 
4. ODPOWIEDZIALNOŚĆ PODMIOTÓW ZBIOROWYCH W ZWIĄZKU Z UZYSKANIEM KORZYŚCI MAJĄTKOWYCH

W świetle obowiązującej ustawy, wobec podmiotu można zastosować jeden rodzaj kary, tj. karę pieniężną. Z kolei środki karne są rozumiane dwojako: w zakresie węższym, obowiązującym w kodeksie karnym (tj. przepadek, podanie wyroku do publicznej wiadomości), jak również w kontekście szerszym obejmującym każdy środek reakcji na czyn przestępny ${ }^{47}$, tj.: zakaz promocji i reklamy; zakaz korzystania $\mathrm{z}$ dotacji i subwencji lub innych form wsparcia finansowego; środków ze wspólnej polityki rolnej i środków pochodzących z szeroko rozumianych funduszy strukturalnych; zakaz korzystania z pomocy organizacji międzynarodowych; zakaz ubiegania się o zamówienia publiczne.

Jeżeli chodzi o kary pieniężne, zgodnie z art. 7 u.o.p.z. wobec podmiotu zbiorowego sąd orzeka karę pieniężną w wysokości od 1 tys. zł do $5 \mathrm{mln}$ zł, nie wyższą jednak niż 3\% przychodu osiągniętego w roku obrotowym, w którym popełniono czyn zabroniony, będący podstawą odpowiedzialności podmiotu zbiorowego. Tak skonstruowany przepis budzi wątpliwości, związane choćby z zakresem podmiotowym, bowiem art. 2 u.o.p.z. konstruuje szeroką definicję podmiotów zbiorowych, natomiast ustawa o podatku dochodowym od osób prawnych ${ }^{48}$ wyłącza z tego zakresu spółki osobowe. Można zatem przyjąć, że ustawodawca odwołuje się do tej ustawy przy ustaleniu wysokości przychodu osiągniętego w roku obrotowym, natomiast zupełnie pominął zakres przedmiotowy w niej określony. Jak wskazuje Dorota Habrat ${ }^{49}$, w spółkach osobowych opodatkowaniu podlegają wspólnicy - w zależności od formy organizacyjnej - podatkiem dochodowym od osób fizycznych bądź od osób prawnych. Zatem, czy określenie przychodu na zasadach określonych w ustawie o podatku dochodowym od osób prawnych w przypadku spółek nie będzie stanowiło fikcji prawnej?

\footnotetext{
47 A. Marek, Prawo karne. Zagadnienia teorii i praktyki, Warszawa 1997, s. 267-294.

48 Tekst jedn.: Dz. U. z 2018 r. poz. 1036 ze zm.

49 D. HABRAT, Analiza kar i środków karnych określonych w ustawie o odpowiedzialności podmiotów zbiorowych za czyny zabronione pod groźbą kary, «Czasopismo Prawa Karnego i Nauk Penalnych» 91.1/2015, s. 94-96.
} 
Na gruncie projektu nie przewidziano kar pieniężnych związanych $\mathrm{z}$ osiagganym przychodem $\mathrm{w}$ roku obrotowym, ustawodawca zaproponował natomiast dwa rodzaje sankcji: karę finansową oraz rozwiązanie podmiotu zbiorowego, a także wiele środków karnych, które w większości stanowią powtórzenie obecnych rozwiązań (zakaz reklamy, zakaz korzystania z dotacji, podanie wyroku do publicznej wiadomości itp.). Sztandarowym założeniem nowej ustawy miało być zwiększenie kar za przestępstwa podmiotu zbiorowego i derogowanie przepisów uzależniających odpowiedzialność finansową od osiągniętego przychodu w roku obrotowym. Stosownie do tych założeń znacznie zwiększono zakres kar pieniężnych, jakie sąd może wymierzyć podmiotowi zbiorowemu - od 30 tys. zł do $30 \mathrm{mln}$ zł, a w kwalifikowanych przypadkach na przykład przewidzianych w art. 12 ust. $1^{50}$ projektu, kara finansowa może wynieść nawet $60 \mathrm{mln}$ zł. Bardzo szerokie ukształtowanie kary pieniężnej budzi wątpliwości w zakresie jej proporcjonalności, która w ujęciu materialnym związana jest $\mathrm{z}$ dyrektywą współmierności kary do stopnia winy, czyli takiego dobrania ustawowego zagrożenia karnego, aby pozostawała w jak najściślejszym związku ze szkodą i zakresem odpowiedzialności sprawcy ${ }^{51}$.

W projekcie ustawy ${ }^{52}$ wskazano, że założeniem zmian jest indywidualizacja odpowiedzialności karnej oraz stworzenie sądowi odpowiednich ram do stosowania wymiaru sprawiedliwości. Jednakże najsurowsza kara w typie podstawowym jest tysiąckrotnie wyższa niż kara najłagodniejsza. Taka rozpiętość kar pozostawia szeroki margines niepewności po stronie podmiotu zbiorowego, zwłaszcza że w projekcie brakuje

50 Chodzi o brak przeprowadzenia postępowania w zakresie niezgłoszonym przez sygnalistów.

51 M. KróLIKowski, Sprawiedliwość karania w społeczeństwach liberalnych. Zasada proporcjonalności, Warszawa 2005, s. 67-77.

52 W ocenie skutków regulacji, załączonych do projektu ustawy o odpowiedzialności podmiotów zbiorowych za czyny zabronione pod groźbą kary, ustawodawca wskazywał, że znikoma efektywność obecnych uregulowań prawnych wynika z niskiego wymiaru kar oraz ściganiu drobnych przedsiębiorców. Nowa ustawa ma realnie karać za przestępstwa gospodarcze oraz dostosowywać kary pieniężne do ich możliwości finansowych. Por. https://legislacja.rcl.gov.pl/docs//2/12312062/12511926/12511927/ dokument372230.pdf, s. 72 i n. (dostęp: 23 grudnia 2018 r.). 
szczegółowych dyrektyw wymiaru kary, a także stwarza problemy interpretacyjne i praktyczne dla organu stosującego prawo. Poza tym budzi on uwagi natury konstytucyjnej ${ }^{53}$, a brak uzależnienia wysokości kary od dochodów osiąganych przez podmiot może doprowadzić do jego niewypłacalności.

Kary finansowe nie są jednak najdotkliwszą sankcją, jaką proponuje projekt ustawy. Zgodnie $\mathrm{z}$ art. 18 ust. 1 projektu, in principio, sąd może orzec o rozwiązaniu podmiotu zbiorowego, kiedy w całości lub w znacznej części służył do popełnienia czynu zabronionego zagrożonego karą nie niższą niż pięć lat pozbawienia wolności. Przepis ten nie daje odpowiedzi na pytanie, jak rozumieć zwrot „w znacznej części służył do popełnienia czynu zabronionego”. Można wyobrazić sobie sytuację, w której pracownik przedsiębiorstwa, licząc na premię, zaoferuje wójtowi 20 tys. zł łapówki w zamian za wybranie oferty przedsiębiorstwa, w którym pracuje. W tak zaprezentowanym stanie faktycznym mamy do czynienia z przestępstwem przekupstwa z art. 229 k.k., za które grozi kara od 6 miesięcy do 8 lat pozbawienia wolności. Zatem zachodzą wszystkie przesłanki z art. 18 ust. 1 projektu, uprawniające sąd do rozwiązania osoby prawnej, jeżeli przyjmiemy interpretację, że to przedsiębiorstwo służyło sprawcy do popełnienia czynu zabronionego w postaci udzielenia łapówki (np. pracownik działał w imieniu podmiotu zbiorowego). Oczywiście zgodnie z art. 18 ust. 2 powyższego projektu podmiot może uniknąć kary, jeżeli wykaże, że dochował zasad należytej staranności, na przykład zastosował odpowiedni nadzór czy odpowiednio zweryfikował zatrudnionych u siebie pracowników. Zatem z przedstawionych przepisów wynika, że ciężar dowodu spoczywa na oskarżonym.

53 Jak wielokrotnie wskazywał Trybunał Konstytucyjny, częścią zasady demokratycznego państwa prawnego jest nakaz respektowania przez ustawodawcę zasad przyzwoitej legislacji. Jest to m.in. wymaganie określoności przepisów, które muszą być formułowane w sposób poprawny, precyzyjny i jasny. Standard ten wymagany jest zwłaszcza wtedy, gdy chodzi o ochronę praw i wolności; zob. wyrok TK z 12 czerwca 2008 r., K 50/05 («OTK-A» 5/2008, poz. 79), wyrok TK z 7 stycznia 2004 r., K 14/03 («OTK-A»1/2004, poz. 1). 
Zgodnie z art. 5 k.p.k. ciężar dowodu obciąża oskarżyciela. Dotyczy to zarówno obowiązku dowodzenia (tzw. formalny ciężar dowodu), jak i skutków niepowodzeń dowodowych (tzw. materialny ciężar dowodu) ${ }^{54}$. Nie sposób odnieść wrażenia, że w zaproponowanym przez rząd projekcie ustawy jest dokładnie odwrotnie. To podmiot zbiorowy musi wykazać, że dopełnił zasad należytej staranności i dlatego nie powinien ponieść odpowiedzialności ${ }^{55}$. W przypadku osoby fizycznej to prokurator w postępowaniu przygotowawczym, a następnie sąd mają udowodnić winę oskarżonego. W przypadku osoby prawnej, takiego obowiązku nie ma, co powoduje ryzyko pociągnięcia do odpowiedzialności podmiotu zbiorowego wraz z równoczesnym oportunistycznym zaniechaniem ustalania sprawcy czynu i pociągania go do odpowiedzialności, co każdorazowo wymaga uwzględnienia wielu dyrektyw wynikających $\mathrm{z}$ kodeksu postępowania karnego ${ }^{56}$.

Obok kary wiele wątpliwości budzą zagadnienia związane ze środkami karnymi. Na gruncie obecnej ustawy sąd obligatoryjnie orzeka przepadek $^{57}$ wobec podmiotu zbiorowego (art. 8 u.o.p.z.). Przy czym szczególnie problematyczne wydaje się orzeczenie przepadku równowartości przedmiotu lub korzyści majątkowej pochodzących choćby pośrednio z czynu zabronionego. Tak sformułowany przepis prowadzi do wniosku, że należy orzec zarówno przepadek przedmiotu czy korzyści pochodzącej z przestępstwa, jak i jego równowartość. Poza tym problem budzi również określenie stopnia „pośredniości” przedmiotów

54 S. Waltoś, P. Hofmański, Proces karny. Zarys systemu, Warszawa 2018, s. 254-256.

55 T. Gardocka, K. Dudka, K. Paluszkiewicz, Zagadnienie dowodowe w procesie karnym, Warszawa 2017, s. 7-16.

56 Szerzej o zasadzie oportunizmu i legalizmu M. Rogacka-Rzewnicka, Oportunizm i legalizm ścigania przestępstw $w$ świetle współczesnych przeobrażeń procesu karnego, Warszawa 2007, s. 50-55.

57 Zgodnie $\mathrm{z}$ art. 8 u.o.p.z. wobec podmiotu zbiorowego orzeka się przepadek: 1) przedmiotów pochodzących chociażby pośrednio z czynu zabronionego lub które służyły lub były przeznaczone do popełnienia czynu zabronionego; 2) korzyści majątkowej pochodzącej chociażby pośrednio z czynu zabronionego; 3) równowartości przedmiotów lub korzyści majątkowej pochodzących chociażby pośrednio z czynu zabronionego. 
pochodzących z przestępstwa. Co do zasady pośrednio z przestępstwa pochodzi każdy przedmiot, u podstaw którego leżało wejście w niedozwolone posiadanie jakiegoś innego przedmiotu, wprowadzonego następnie do obrotu, jeśli tylko przedmiot ten znajduje się w posiadaniu podmiotu zbiorowego, względem którego toczy się postępowanie $k^{2} e^{58}$. Zrównanie obligatoryjnego orzekania o przepadku przedmiotów pochodzących pośrednio i bezpośrednio z przestępstwa wydaje się nazbyt represyjne. Ponadto istnieje również ryzyko, że podmiot zbiorowy dwukrotnie poniesie tę samą konsekwencję: najpierw na podstawie art. $45 \S 3$ k.k. utraci przedmioty znajdujące się w jego samoistnym posiadaniu, po raz drugi zaś - już na podstawie art. 8 u.o.p.z., wobec obligatoryjności przepadku - orzeczony zostanie przepadek ich równowartości ${ }^{59}$.

Nowa ustawa również reguluje instytucje przepadku, ale jego konstrukcja budzi podobne kontrowersje jak obowiązujące dotychczas rozwiązania. Z punktu widzenia techniki legislacyjnej, nie wiedzieć czemu, ustawodawca w rozdziale trzecim zatytułowanym „Odpowiedzialność finansowa i odszkodowawcza podmiotów zbiorowych" umieścił dwa bodaj najbardziej charakterystyczne kodeksowe środki karne: przepadek i nawiązka. Tymczasem w rozdziale 5 „Kary i środki karne orzekane wobec podmiotów zbiorowych", obok kar znalazły się środki karne pozakodeksowe (por. art. 16 projektu). Zasadne byłoby umieszczenie kar i środków karnych razem w rozdziale 2 poświęconym odpowiedzialności podmiotów zbiorowych za czyn zabroniony.

Sama konstrukcja przepadku zdaniem ustawodawcy wypełnia lukę w prawie, w ten sposób, że kryminalizuje sam fakt powołania do życia podmiotu zbiorowego tylko w celu przestępczym lub w celu ukrycia nielegalnego pochodzenia środków. Zgodnie $\mathrm{z}$ art. 9 projektowanej ustawy podmiot zbiorowy poniesie odpowiedzialność, w sytuacji gdy nie będzie możliwe pociągnięcie go do materialnej odpowiedzialności na podstawie art. 5 lub art. 6 projektowanej ustawy. Można wyobrazić

58 J. GieZeK, G. ŁabUdA, System sankcji w ustawie o odpowiedzialności podmiotów zbiorowych za czyny zabronione pod groźbą kary, «Prokuratura i Prawo»11-12/2004, s. $81-110$.

59 J. GIeZeK, G. Łabuda, op. cit., s. 111-114. 
sobie sytuację, w której nie popełniono czynu zabronionego w ramach podmiotu zbiorowego, przy czym sprawca czynu zabronionego, tj. osoba fizyczna, nie został skazany. W zamyśle ustawodawcy proponowana regulacja stanowić ma uzupełnienie art. 44a k.k., który dotyczy przepadku przedsiębiorstwa. Dodatkowym warunkiem zrealizowania odpowiedzialności podmiotu zbiorowego jest osiągnięcie korzyści majątkowej przez ten podmiot w wysokości przekraczającej 500 tys. zł. ${ }^{60}$ Jednakże trudno oprzeć się wrażeniu, że ustawodawca w art. 9 projektu wprowadza wstępne warunki odpowiedzialności podmiotu zbiorowego. W definicji zaproponowanej w powyższym artykule zawarto wyrażenie „W razie popełnienia czynu zabronionego”, które może być odczytywane jako definitywne twierdzenie o popełnieniu przestępstwa przez określoną osobę, które sugeruje konieczność ustalenia takiego faktu, ergo prejudykatu.

Jeżeli chodzi o środki karne należące do szerszej grupy, nieujętej w kodeksie karnym - charakterystycznej dla regulacji związanej ze specyfiką podmiotów zbiorowych, ustawodawca przy ich wyborze kierował się rekomendacjami Rady Europy z 20 października 1988 r. ${ }^{61}$, które nie przystawały do polskiej specyfiki podmiotów zbiorowych i ówczesnego stanu prawnego. Przykładowo, nie jest jasny przedmio-

60 Ustawodawca, uzasadniając wybór kwoty 500 tys. zł, wskazuje, że jest ona wyższa niż kwota odpowiadająca mieniu znacznej wartości (zgodnie z art. $115 \$ 2$ kwota ta wynosi 200 tys. zł), ale jest niższa niż mienie znacznej wartości (zgodnie z art. $115 \$ 5$ wynosi ona $1 \mathrm{mln} \mathrm{zl})$.

${ }_{61}$ Rekomendacja Rady Europy nr 18/88, przyjęta przez Komitet Rady Europy 20 X 1988 r. proponuje stosowanie wobec podmiotów zbiorowych następujących sankcji: ostrzeżenie; nagana; poręka; kaucja; stwierdzenie odpowiedzialności bez wymierzania kary lub środków karnych; grzywna; orzeczenie zakazu prowadzenia określonej działalności, w szczególności przeznaczenia produktów i usług na rynek; przepadek narzędzi służących do popełnienia przestępstwa oraz przedmiotów z niego pochodzących, także korzyści płynących z działalności przestępczej; zakaz korzystania z przywilejów; zakaz reklamy produktów i usług; anulowanie pozwolenia na działalność; poddanie osoby prawnej pod nadzór wyznaczony przez sąd; zamknięcie przedsiębiorstwa; rozwiązanie przedsiębiorstwa; nałożenie zabezpieczenia praw majątkowych na rzecz osoby pokrzywdzonej; naprawienie szkody; zobowiązanie do przywrócenia rzeczy do stanu poprzedniego; ogłoszenie orzeczenia w środkach masowego przekazu ze wskazaniem treści wyroku. 
towy zakres pojęcia zakazu promocji lub reklamy, wynikający z art. 9 ust. 1 pkt 1 u.o.p.z. Jest w nim mowa wyłącznie o promocji lub reklamie prowadzonej działalności, wytwarzanych lub sprzedawanych wyrobów, świadczonych usług lub udzielanych świadczeń; nie zaś o reklamie samego podmiotu jako marce bądź instytucji ${ }^{2}$. Wątpliwości budzi również zakaz korzystania $z$ dotacji, subwencji lub innych form wsparcia finansowego, gdyż istniejące dotychczas definicje tych pojęć odnoszą się do określonych sfer finansów publicznych. Rozwiązania te zostały powielone w nowej ustawie (por. art. 16 projektu), ale ustawodawca nie rozwiewa powyższych wątpliwości. Przykładowo, z art. 20 projektowanej ustawy również nie wynika, czy zakaz promocji lub reklamy odnosi się tylko do działalności usługowej, czy obejmuje podmiot zbiorowy per se. Co więcej, przepadek mienia lub korzyści majątkowej wskazany w art. 19 ust. 1 projektu tworzy superfluum ustawowe. W art. 9 projektu już uregulowano sytuację, w której wobec podmiotu zbiorowego można orzec przepadek składników lub praw majątkowych w całości lub w części albo ich równowartości, jeżeli podmiot zbiorowy w całości lub w znacznej części służył lub był przeznaczony do popełnienia tego czynu zabronionego lub ukrycia osiągniętej z niego korzyści. Jednocześnie w art. 19 ust. 1 projektu ustawodawca wskazał, że przepadek mienia lub korzyści majątkowej orzeka się, jeżeli pochodzi bezpośrednio z czynu zabronionego albo było użyte do popełnienia tego czynu. Ergo mienie lub korzyść majątkowa wchodziły do składników lub praw majątkowych, o których mowa w art. 9 ust. 1.

\section{KonkLuzje}

Projektowana ustawa powoduje rewolucję w dotychczasowych rozwiązaniach prawnych i stanowi swego rodzaju podsumowanie wieloletniej dyskusji w doktrynie prawa karnego, dotyczącej możliwości

62 B. Nita, Materialnoprawne i procesowe założenia ustawy o odpowiedzialności podmiotów zbiorowych za czyny zagrożone pod groźba kary, cz. II, «Radca Prawny» 6/2003, s. 16-44. 
i konsekwencji zmiany modelu odpowiedzialności szeroko rozumianych osób prawnych. Ramy niniejszej pracy nie pozwalają na szczegółową analizę wszystkich zagadnień zawartych w projektowanej ustawie (np. odpowiedzialność wobec osób sygnalizujących nieprawidłowości, zarządu przymusowego czy działania ustawy wstecz). W ogólnej ocenie projekt zasługuje na aprobatę. Odejście od konieczności uprzedniego skazania osoby fizycznej wprowadza europejskie standardy w zakresie odpowiedzialności karnej podmiotów zbiorowych. We współczesnym świecie nie można pomijać odpowiedzialności szeroko rozumianych osób prawnych, a nawet najdoskonalszy model odpowiedzialności osób fizycznych nie wystarczy, aby skutecznie zwalczać przestępczość gospodarczą. W tego rodzaju przestępstwach niejednokrotnie wykorzystywane są osoby prawne (np. przedsiębiorstwa), a przestępcy często pozostają bezkarni, bo korzystają ze słabości państwa. Niestety, powyższy projekt nie zawsze dostarcza środków koniecznych do skutecznego zwalczania tego typu przestępstw.

Jednym $\mathrm{z}$ istotnych mankamentów nowej ustawy jest nieprzystosowanie proponowanych rozwiązań do wymagań, jakie wynikają z przynależności jego materii regulacyjnej do sfery penalnej. Adresat normy powinien mieć jasną i kompletną informację, jakie zachowania lub zaniechania grożą odpowiedzialnością karną. Tymczasem z projektu ustawy nie wynika jednoznacznie, kiedy podmiot zbiorowy pozostaje w związku z osobą fizyczną, która popełnia przestępstwo (art. 5 ust. 1 projektu) albo kiedy nie dochowuje zasad należytej staranności w wyborze bądź nadzorze osoby fizycznej (art. 6 ust. 3 pkt 1 projektu). Brak określoności przepisów jest tym bardziej niepokojący, że kary przewidziane w projekcie są surowe, począwszy od dotkliwych kar pieniężnych, poprzez środki karne pozwalające na zamknięcie oddziału przedsiębiorstwa czy zakaz prowadzenia określonej działalności gospodarczej, a skończywszy na likwidacji podmiotu zbiorowego. Same przesłanki pozwalające na likwidację podmiotu również nie zostały doprecyzowane, bowiem projekt ustawy nie daje odpowiedzi na pytanie, kiedy podmiot w całości lub w znacznej części służył popełnieniu przestępstwa (art. 18 ust. 1 projektu). O dalszym istnieniu podmiotu zbiorowego może decydować indywidualna interpretacja sprawy przez konkretnego sędziego, 
a obowiązek wykazywania należytej staranności (ergo udowodnienie swojej niewinności) spoczywa na samym podmiocie. Zastrzeżenia budzą również regulacje dotyczące kar pieniężnych, których wymiar nie jest proporcjonalny i przy braku odpowiednich dyrektyw wymiaru kary pozostawia szeroki margines niepewności po stronie podmiotu zbiorowego. Nie ma wątpliwości, że projekt przewiduje dużo bardziej restrykcyjne sankcje niż obecnie obowiązująca ustawa. Zwiększenie kar za przestępstwa popełniane przez podmioty zbiorowe jest w pełni uzasadnione, ale sankcje te powinny być precyzyjnie określone i zgodne $\mathrm{z}$ wymaganiami stawianymi ustawom karnym ${ }^{63}$. Poza tym ustawodawca nieprawidłowo konstruuje definicję podmiotu zbiorowego. Na gruncie nowych przepisów nadal pozostaje problematyczny status spółki cywilnej jako podmiotu zbiorowego. Nie wiadomo również, dlaczego ustawodawca wyłącza stosowanie nowej ustawy wobec Skarbu Państwa. Projekt powiela także błędy, które pojawiały się na gruncie obowiązującej ustawy, w zakresie środków karnych, tj. zakaz promocji i reklamy bądź zakaz ubiegania się o szeroko rozumiane subwencje i dotacje.

Ustawodawca wielokrotnie powoływał się w projekcie na wzorce pochodzące z Europy Zachodniej, wskazując, że przyjęcie rozwiązań francuskich czy holenderskich przyczyni się do skuteczniejszego zwalczania przestępczości gospodarczej. Z tym że w obu tych państwach odpowiedzialność podmiotów zbiorowych regulowana jest w rodzimych kodeksach karnych, dzięki czemu nie ma wątpliwości w zakresie koncepcji regulacyjnych (tj. odpowiedniego stosowania przepisów), a odpowiedzialność osób prawnych wpisuje się na równi z osobami fizycznymi w system prawa karnego. De lege ferenda, należałoby rozważyć uregulowanie odpowiedzialności podmiotów zbiorowych w kodeksie karnym (i odpowiednio w kodeksie postępowania karnego i kodeksie karnym skarbowym), zamiast tworzyć kolejną ustawę, która z jednej strony powiela błędy występujące w obowiązującym akcie prawnym, a z drugiej dostarcza nowe ${ }^{64}$.

63 A. Barczak-Oplustil, Obowiązywanie zasady 'nullum crimen sine lege'. Wybrane problemy, «Czasopismo Prawa Karnego i Nauk Penalnych» 17.3/2013, s. 20-27.

64 Stanowisko to podziela również Rada Legislacyjna w Opinii o projekcie ustawy o odpowiedzialności podmiotów zbiorowych za czyny zabronione pod groźbą kary 
ODPOWIEDZIALNOŚĆ PODMIOTÓW ZBIOROWYCH NA NOWYCH ZASADACH A OBECNE ROZWIĄZANIA PRAWNE.

WYBRANE ZAGADNIENIA

\section{Streszczenie}

Celem artykułu jest porównanie dotychczasowych regulacji w zakresie odpowiedzialności podmiotów zbiorowych z rozwiązaniami zaproponowanymi w rządowym projekcie ustawy oraz ich ocena. Konieczność zmian wynika z niskiej efektywności dotychczasowych rozwiązań prawnych, jak również z potrzeby dostosowania przepisów do wymogów formułowanych przez OECD oraz konwencje międzynarodowe, których Polska jest stroną. Projekt znosi między innymi konieczność uprzedniego skazania osoby fizycznej oraz znacznie modyfikuje kary i środki karne, które mogą być zastosowane wobec podmiotu zbiorowego. Autorka rozpoczyna rozważania od przedstawienia definicji podmiotu kolektywnego na gruncie obecnych i przyszłych rozwiązań. Następnie poddaje analizie konstrukcje związane z popełnieniem przestępstwa przez szeroko rozumiane osoby prawne i zakres odpowiedzialności w związku z uzyskaniem korzyści majątkowych, ze szczególnym uwzględnieniem kar i środków karnych. W konkluzji autorka wyciąga określone wnioski i przedstawia postulaty de lege ferenda.

\section{Corporate Liability under the new Provisions in Polish law and the Current Legal Solution: Selected Issues}

\section{Summary}

The main purpose of this paper is to compare and assess the current regulations in Polish law regarding corporate liability with the arrangements proposed in the government's new draft bill. There is a need for amendment due to the low efficiency of the existing legal provisions,

i zmianie niektórych ustaw, https://legislacja.rcl.gov.pl/projekt/12312062/kata$\log / 12511926 \# 12511926$ (dostęp: 24 grudnia 2018 r.). 
and to adapt the Polish regulations to the requirements of the OECD and international conventions to which Poland is a party. The draft bill eliminates the need for the culpable individual's previous conviction and brings in a significant modification in the penalties for corporate liability. I begin by giving the current and prospective definition of podmiot kolektywny (a collective entity, viz. a corporation) in Polish law, and proceed to the analysis of the legal constructs associated with offences committed by corporations in the broad sense of the term, and the scope of corporate liability in connection with a corporation's acquisition of property benefits, with particular emphasis on penalties and punitive measures. I sum up by presenting my conclusions and postulates for the changes in Polish law needed in this respect.

Słowa kluczowe: podmiot zbiorowy; przestępczość gospodarcza; kary i środki karne; prejudykat

Keywords: corporation; white collar crime; penalties and punitive measures; prejudication

\section{Literatura}

Antoniak-DróżDż A., Zakres podmiotowy ustawy o odpowiedzialności podmiotów zbiorowych, «Państwo i Prawo» 72.2/2017, s. 111-120.

Barczak-Opustil A., Obowiązywanie zasady nullum crimen sine lege. Wybrane problemy, «Czasopismo Prawa Karnego i Nauk Penalnych»17.3/2013, s. 20-27.

BARtosiewicz A., Spótki osobowe a odpowiedzialność podmiotów zbiorowych, «Przegląd Prawa Handlowego» 9/2013, s. 53-58.

Coffe J.C., Does Unlawful Mean Criminal?: Reflections on the Disappearing Tort/Crime Distinction in American Law, "Center for Law and Economic Studies, Columbia University School of Law» 193.71/1991, s. 216-219.

DARKowski T., Plany ministerstwa sprawiedliwości zmian legislacyjnych stużacych ograniczeniu szarej strefy w Polsce, https://www.pwc.pl/pl/pdf/szara-strefa-2016.pdf (dostęp: 12 grudnia 2018 r.).

Gardocka T., Dudka K., Paluszkiewicz K., Zagadnienie dowodowe w procesie karnym, Warszawa 2017, s. 7-16. 
Gardocki L., Pojęcie przestępstwa i podział przestępstw w polskim prawie karnym, «Annales Universitatis Mariae Curiae-Sklodowska Lublin-Polonia» 15.2/2013, s. 29-39.

GiezeK J., ŁABUda G., System sankcji w ustawie o odpowiedzialności podmiotów zbiorowych za czyny zabronione pod groźbą kary, «Prokuratura i Prawo» 11-12/2004, s. 81-114.

Habrat D., Analiza kar i środków karnych określonych w ustawie o odpowiedzialności podmiotów zbiorowych za czyny zabronione pod groźbą kary, «Czasopismo Prawa Karnego i Nauk Penalnych» 91.1/2015, s. 94-96.

Karkut D., Odpowiedzialność podmiotów zbiorowych-ujęcie prawnoporównawcze, http://bibliotekacyfrowa.pl/Content/42786/04_Daniel_Karkut.pdf (dostęp: 9 grudnia 2018 r.).

Kahana V.S., A Political Economy Theory Of Corporate Crime Legislation, «Boston U.L.REV Working Paper» 220.3-4/2003, s. 3-9.

Krawczyк A., Gisman A., Criminal compliance jako środek zapobiegania odpowiedzialności podmiotów zbiorowych za czyny zabronione pod groźba kary, «Monitor Prawa Handlowego»1/2015, s. 3-5.

KRóLIKowsкi M., Sprawiedliwość karania w społeczeństwach liberalnych. Zasada proporcjonalności, Warszawa 2005, s. 67-77.

Marek A., Prawo karne. Zagadnienia teorii i praktyki, Warszawa 1997, s. 267-294.

Maguard Y., Les grandes articles du code pénal, Paris 2017, s. 60-71.

Nita B., Materialnoprawne i procesowe założenia ustawy o odpowiedzialności podmiotów zbiorowych za czyny zagrożone pod groźba kary, cz. II, «Radca Prawny» 6/2003, s. 16-44.

Nowaк C., Dostosowywanie prawa polskiego do instrumentów międzynarodowych dotyczacych korupcji - raport, Warszawa 2004, s. 3-35.

OlejniczaK A., art. 355 k.c., [w:] Kodeks cywilny. Komentarz, III: Zobowiązania -część ogólna², red. A. KidyBA, Lex 2014.

Ondrysz K., Przesłanki odpowiedzialności podmiotów zbiorowych za czyny zabronione pod groźbą kary - po nowelizacji, «Nowa Kodyfikacja Postępowania Karnego» 20/2016, s. 89-105.

Rogacka-Rzewnicka M., Oportunizm i legalizm ścigania przestępstw wświetle wspótczesnych przeobrażeń procesu karnego, Warszawa 2007, s. 50-55.

Toszka S., Odpowiedzialność podmiotów zbiorowych we francuskim i polskim prawie karnym. Analiza porównawcza, «Czasopismo Prawa Karnego i Nauk Penalnych» 12.1/2008, s. 282-285. 
Waltoś S., Hofmański P., Proces karny. Zarys systemu, Warszawa 2018, s.254-256.

Wróbel W., Zoll A., Polskie prawo karne, część ogólna2, Kraków 2010, s. 101-102.

ZALEWsKi W., Odpowiedzialność podmiotu zbiorowego w prawie karnym -w poszukiwaniu racjonalności, «Gdańskie Studia Prawnicze» 37.1/2017, s. 389-404. 